\title{
Ciężka postać rabdomiolizy po biegu górskim u chorego z podejrzeniem ostrego zespołu wieńcowego
}

\author{
Rhabdomyolysis after mountain running in patient \\ with suspicion of acute coronary syndrome
}

\author{
Przemysław Młodożeniec ${ }^{1}$, Anna Stec ${ }^{2}$, Dawid Bąkowski ${ }^{2}$, Beata Wożakowska-Kapłon ${ }^{2,3}$ \\ ${ }^{1}$ Oddział Chorób Wewnętrznych i Diabetologii Szpitala Kieleckiego św. Aleksandra \\ ${ }^{2}$ I Klinika Kardiologii i Elektroterapii Świętokrzyskiego Centrum Kardiologii w Kielcach \\ ${ }^{3}$ Wydział Lekarski i Nauk o Zdrowiu Uniwersytetu Jana Kochanowskiego w Kielcach
}

\section{Streszczenie}

W pracy przedstawiono przypadek 34-letniego mężczyzny przyjętego do kliniki kardiologii z podejrzeniem ostrego zespołu wieńcowego, po utracie przytomności w wyniku ekstremalnego wysiłku fizycznego w trakcie biegu górskiego. Podczas hospitalizacji wystąpiły wzrost stężeń markerów uszkodzenia mięśni, żółtaczka oraz zwiększenie aktywności aminotransferaz i stężenia bilirubiny; rozpoznano rabdomiolizę. W trakcie pobytu w klinice objawy kliniczne ustąpiły, a wykładniki laboratoryjne uległy poprawie.

Słowa kluczowe: ekstremalny wysiłek fizyczny, rabdomioliza, uszkodzenie wątroby, uszkodzenie nerek, ostry zespół wieńcowy

Folia Cardiologica 2017; 12, 3: 298-302

\section{Wstęp}

Rabdomioliza to stan kliniczny będący skutkiem uwalniania do krwiobiegu zawartości komórek mięśni poprzecznie prążkowanych wskutek uszkodzenia ich błon komórkowych [1]. W wyniku uszkodzenia miocytów kinaza fosfokreatynowa (CPK, creatinine phosphokinase) zostaje uwolniona do krwiobiegu - oznaczenie jej aktywności stanowi podstawę diagnostyki rabdomiolizy. Definicja zaakceptowana przez amerykańską Agencję ds. Żywności i Leków (FDA, Food and Drug Administration) wymaga zaistnienia zarówno podwyższonej aktywności CPK ponad 10000 j./l, jak i cech uszkodzenia narządowego, zwykle ostrej niewydolności nerek [2]. Stwierdzenie aktywności CPK ponad 15000 j./I wskazuje na ciężką postać rabdomiolizy [3]. Do jej poważnych powikłań należą: ostre uszkodzenie nerek, ostra niewydolność oddechowa, rozsiane wykrzepianie wewnątrznaczyniowe [1].

W piśmiennictwie istnieje rozróżnienie, zgodnie z którym terminem „mialgia” określa się dolegliwości bólowe i osłabienie mięśni, terminem miositis, jeżeli wyżej wymienionym objawom towarzyszy wzrost aktywności CPK, a mianem rabdomiolizy stan, w którym dolegliwościom bólowym mięśni i wzrostowi aktywności CPK towarzyszy mioglobinuria. Jeśli aktywność CPK przekracza 10-krotnie górną granicę normy (ULN, upper limit of normal), a w moczu chorego stwierdza się obecność mioglobiny, można rozpoznać rabdomiolizę. Niemniej jednak opisana klasyczna triada objawów (ból mięśni i osłabienie siły mięśniowej, mioglobinuria) występuje tylko u 1/3 pacjentów [4].

Praca powstała w ramach realizacji projektu: „Zakup wyposażenia I Klinicznego Oddziału Kardiologii i Pracowni Elektrofizjologii szansą na zwiększenie innowacyjności Wojewódzkiego Szpitala Zespolonego w Kielcach” współfinansowanego przez Unię Europejską ze środków Europejskiego Funduszu Rozwoju Regionalnego w ramach Regionalnego Programu Operacyjnego Województwa Świętokrzyskiego na lata 2007-2013 
Tabela 1. Wartości wybranych parametrów laboratoryjnych w kolejnych dobach hospitalzacji

\begin{tabular}{|c|c|c|c|c|c|c|c|c|}
\hline Parametr/doba & 1. & 2. & 3. & 4. & 5. & 6. & 7. & 10. \\
\hline WBC $[K / \mu \mathrm{ll}]$ & 16,02 & & 5,9 & & & & 9,19 & 7,44 \\
\hline Stężenie Hb [g/dl] & 12,7 & & 13 & & & & 14,2 & 13,1 \\
\hline Stężenie D-dimerów [ug/l] & 3975 & & 5735 & & 520 & & 360 & \\
\hline Stężenie TnT [ng/l] & $396,2 / 294,2$ & & 83,6 & & 45 & & 34,6 & 12,1 \\
\hline Aktywność CK-MB [j./l] & $40 / 46$ & & 100 & & 107 & & 71 & 21 \\
\hline Aktywność CPK [j./I] & $3278 / 5258$ & & 19881 & & 27120 & & 17106 & 2284 \\
\hline Stężenie mocznika [mg/dl] & 51 & & 40 & & 25 & & 25 & 29 \\
\hline Stężenie kreatyniny [mg/dl] & 1,55 & & 1,26 & & 1,03 & & 0,95 & 0,98 \\
\hline eGFR wg MDRD [ml/min] & 54,9 & & 70 & & 88 & & 96,5 & 93,2 \\
\hline Stężenie potasu $(\mathrm{K})[\mathrm{mEq} / \mathrm{l}]$ & 3,8 & & 4,5 & & 4,6 & & 5,1 & 4,6 \\
\hline Stężenie sodu (Na) [mEq/l] & 138 & & 138 & & 135 & & 138 & 138 \\
\hline Stężenie bilirubiny [mg/dl] & 0,81 & & & 3,06 & 2,41 & 1,91 & 1,48 & 1,57 \\
\hline Aktywność AspAT [j./l] & 84 & & & & 1376 & & 636 & 146 \\
\hline Aktywność AIAT [j./I] & 37 & & & & 2991 & & 1888 & 741 \\
\hline Wartość INR & 1,5 & & & & 1,2 & & 1,0 & \\
\hline Aktywność LDH [j./I] & & & & & & 937 & & \\
\hline
\end{tabular}

WBC (white blood count) - liczba krwinek białych; Hb - hemoglobina; TnT - troponina T; CK-MB (creatine kinase myocardial bound) - frakcja sercowa kinazy kreatynowej; CPK (creatinine phosphokinase) kinaza fosfokreatynowa; MDRD - Modification of Diet in Renal Disease; eGFR (estimated glomerular filtration rate) - szacowany współczynnik przesaczania kłebuszkowego; AspAT (aspartate aminotransferase) - aminotransferaza asparaginianowa; AIAT (alanine aminotransferase) - aminotransferaza alaninowa; INR (international normalized ratio) - międzynarodowy współczynnik znormalizowany; LDH (lactate dehydrogenase) - dehydrogenaza mleczanowa

\section{Opis przypadku}

Mężczyznę w wieku 34 lat, niepalącego i nieleczonego przewlekle, o atletycznej budowie, przyjęto do kliniki kardiologii z podejrzeniem ostrego zespołu wieńcowego (ACS, acute coronary syndrome), po utracie przytomności w wyniku ekstremalnego wysiłku fizycznego w trakcie biegu górskiego. Przy przyjęciu stwierdzono wysokie wartości markerów ostrego uszkodzenia mięśnia sercowego: troponiny T (TnT) - 396,2 ng/l, frakcji sercowej kinazy kreatynowej (CK-MB, creatine kinase myocardial bound) $-40 \mathrm{j} . / \mathrm{l}, \mathrm{CPK}-3278 \mathrm{j}$./I (tab. 1). Incydent wystąpił w trakcie biegu górskiego po przebiegnięciu dystansu 9800 m w czasie 45-50 min. Przygotowanie kondycyjne pacjenta polegało na jednogodzinnym treningu fizycznym przez 4 dni w tygodniu przez 4 miesiące, ponadto biegach 45-120-minutowych 3 dni w tygodniu przez 6 tygodni. Należy zaznaczyć brak odpowiedniego nawodnienia przed i w trakcie biegu górskiego. W wywiadzie ustalono, że chory wypił $200 \mathrm{ml}$ wody przed wysiłkiem i nie uzupełniał płynów w trakcie biegu.

Przy przyjęciu do kliniki w spoczynkowym zapisie elektrokardiograficznym (EKG) stwierdzono wyższe odejście punktu J w odprowadzeniach II i aVF, natomiast w wykonanym badaniu echokardiograficznym nie obserwowano odcinkowych zaburzeń kurczliwości, a frakcja wyrzutowa lewej komory (LVEF, left ventricular ejection fraction) wynosiła 70\%. Dodatkowo stwierdzono podwyższone stężenia parametrów wydolności nerek: mocznika - $51 \mathrm{mg} / \mathrm{dl}$, kreatyniny - 1,55 mg/dl. Szacunkowy współczynnik przesączania kłębuszkowego (eGFR, estimated glomerular filtration rate) wyliczony ze wzoru MDRD (Modification of Diet in Renal Disease) wynosił 54,9 ml/min. Stwierdzono

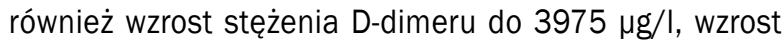
wartości znormalizowanego współczynnika międzynarodowego (INR, international normalized ratio) do 1,5 oraz niewielki wzrost aktywności aminotransferazy asparaginianowej (AspAT, aspartate aminotransferase) do $84 \mathrm{j} . /$ I przy prawidłowej aktywności aminotransferazy alaninowej (AIAT, alanine aminotransferase) - 37 j./I (tab. 1).

Podczas pobytu pacjenta w klinice w badaniu EKG metodą Holtera zarejestrowano bradykardię zatokową w ciągu dnia do 45/min, z ekstrasystolią nadkomorową (260 pobudzeń/d.). W 3. dobie hospitalizacji wystąpiło zażółcenie powłok skórnych, bez nudności, wymiotów, bólu brzucha, biegunki i cech wodobrzusza w badaniu przedmiotowym. Objaw Chełmońskiego był ujemny. W kontrolnych badaniach laboratoryjnych obserwowano rosnąca aktywność aminotransferaz - AspAT do 1376 j./I, a AIAT do $2991 \mathrm{j}$./I. Wykonano diagnostykę przyczyn uszkodzenia wątroby: badanie ultrasonograficzne (USG) jamy brzusznej z oceną żyły wrotnej, badania serologiczne w kierunku infekcji wirusowych: anty-HAV IgM (IgM antibodies to hepatitis $A$ virus), HbsAg (surface antigen of hepatitis $B$ virus), anty-HCV (antibodies to hepatitis C virus), anty-CMV IgG i IgM (IgG and IgM antibodies to cytomegalovirus), HIV Ag/ /Ab Combo (human immunodeficiency virus antigen and 


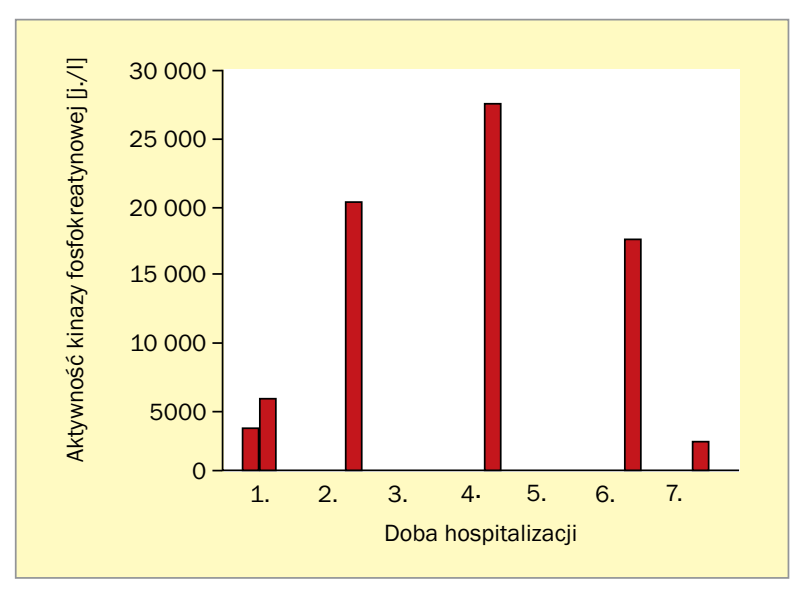

Rycina 1. Zmiany aktywności kinazy fosfokreatynowej (CPK, creatinine phosphokinase) w kolejnych dobach hospitalizacji

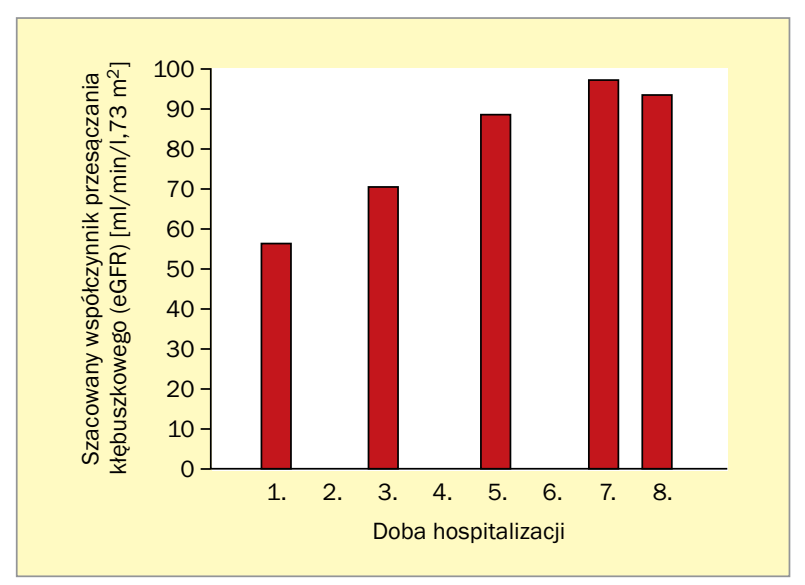

Rycina 2. Zmiany filtracji kłębuszkowej w kolejnych dobach hospitalizacji; eGFR - estimated glomerular filtration rate

antibodies combo assay), anty-EBV IgM (IgM antibodies to Epstein-Barr virus) - wyniki były ujemne. W badaniu EBV IgG (IgG antibodies to Epstein-Barr virus) odnotowano wynik dodatni, wskazujący na przebycie infekcji wirusem Epstein-Barr w przeszłości. Stwierdzono prawidłowe stężenia ceruloplazminy w surowicy krwi oraz prawidłowe stężenia miedzi w dobowej zbiórce moczu. Ocena gospodarki żelaza wykazała podwyższone stężenie ferrytyny, obniżone stężenie żelaza, prawidłowe stężenie transferyny oraz TIBC (total iron binding capacity). Wyliczono wysycenie transferyny żelazem, uzyskując wynik prawidłowy.

Podczas hospitalizacji obserwowano wzrost aktywności CPK ze szczytem w 5. dobie (27120 j./I) (ryc. 1) oraz poprawę parametrów nerkowych, począwszy od 2. doby (ryc. 2).

Uogólnione dolegliwości bólowe mięśni występowały przez 2 pierwsze doby pobytu w klinice, następnie były ograniczone do grupy tylnej mięśni ud i grupy tylnej mięśni lewego ramienia. Dolegliwości zmniejszały się od 7 . doby po incydencie, w 10. dobie ustąpiły. Pacjent negował ciemne zabarwienie moczu, a wynik badania laboratoryjnego moczu z oceną osadu był prawidłowy. Na podstawie całości obrazu klinicznego u chorego rozpoznano rabdomiolizę. Pacjent był konsultowany przez lekarza specjalistę chorób zakaźnych, który potwierdził rozpoznanie oraz wskazał na wtórne uszkodzenie wątroby prawdopodobnie w mechanizmie niedokrwienia. W celu wykluczenia miopatii zapalnej przeprowadzono również konsultację reumatologiczną.

\section{Omówienie}

Podstawowym badaniem w celu rozpoznania rabdomiolizy jest oznaczenie aktywności CPK, która jest markerem o swoistości bliskiej 100\%, natomiast o mniejszej czułości $[5,6]$. Podwyższona aktywność tego enzymu występuje również w przebiegu zawału serca i udaru mózgu, jednak w tych przypadkach wzrost wartości nie jest tak duży jak w przypadku rabdomiolizy. Górna granica wartości referencyjnych dla CPK wynosi około 200 j./I (w zależności od laboratorium), a w laboratorium opisanego ośrodka - $390 \mathrm{j}$./l. W zawale serca aktywność CPK zwykle nie przekracza kilku tysięcy, natomiast w przypadku rozpadu mięśni nierzadko dochodziła do kilkudziesięciu tysięcy [5, 6]. Podwyższenie aktywności CPK występuje po 6-8 godzinach od zadziałania czynnika sprawczego, szczyt aktywności odnotowuje się w 24.-36. godzinie od zadziałania czynnika sprawczego $[5,6]$ i obniża się o $30-40 \%$ w ciągu doby $[2,5]$. Utrzymująca się wysoka aktywność CPK lub jej wzrost dowodzi wciąż aktywnego rozpadu mięśni bądź nasuwa podejrzenie zespołu ciasnoty przedziału powięziowego $[2,5]$.

U przedstawianego pacjenta aktywność CPK narastała do 5. doby hospitalizacji, a dodatkowo utrzymywały się dolegliwości bólowe głównie grupy tylnej mięśni ud, co mogłoby wskazywać na zespół ciasnoty przedziału powięziowego. Ze względu na możliwość wystąpienia uszkodzenia włókien nerwowych w wyniku wyżej wymienionego zespołu pacjent został skonsultowany przez lekarza neurologa.

W przebiegu rabdomiolizy zazwyczaj zwiększa się stężenie mocznika i kreatyniny, wzrasta aktywność aminotransferaz (przy czym specyficzny jest wzrost AspAT, z prawidłowa wartością AIAT), dehydrogenazy mleczanowej, stężenia fosforanów i kwasu moczowego oraz zmniejsza się stężenie wapnia. U około 50\% pacjentów ze zdiagnozowaną rabdomiolizą występuje podwyższone stężenie troponiny I (Tnl) [5].

U omawianego pacjenta doszło do szybkiego wyrównania parametrów nerkowych, natomiast uwagę zwracały wysokie wartości parametrów uszkodzenia wątroby (ryc. 3). W opisywanym przypadku aktywność AIAT była wyższa niż AspAT. Przemawia to raczej za wątrobowym pochodzeniem aminotransferaz. Należy natomiast zaznaczyć, że wzrost stężenia bilirubiny (ryc. 4) miał związek z rozpadem mięśni i nadmierną ilością mioglobiny. Przy diagnostyce różnicowej żółtaczki wzięto pod uwagę choroby infekcyjne, chorobę Wilsona, hemochromatozę oraz choroby naczyń wątrobowych. 


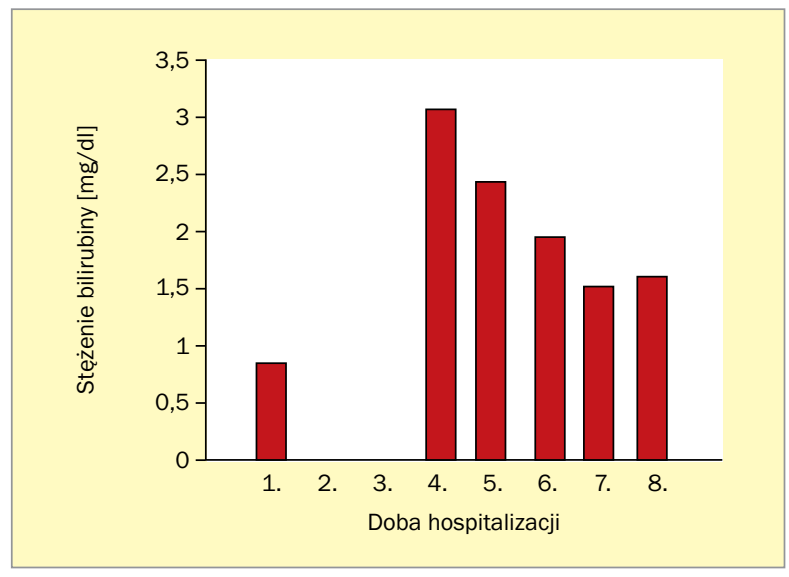

Rycina 3. Zmiany stężenia bilirubiny w kolejnych dobach hospitalizacji

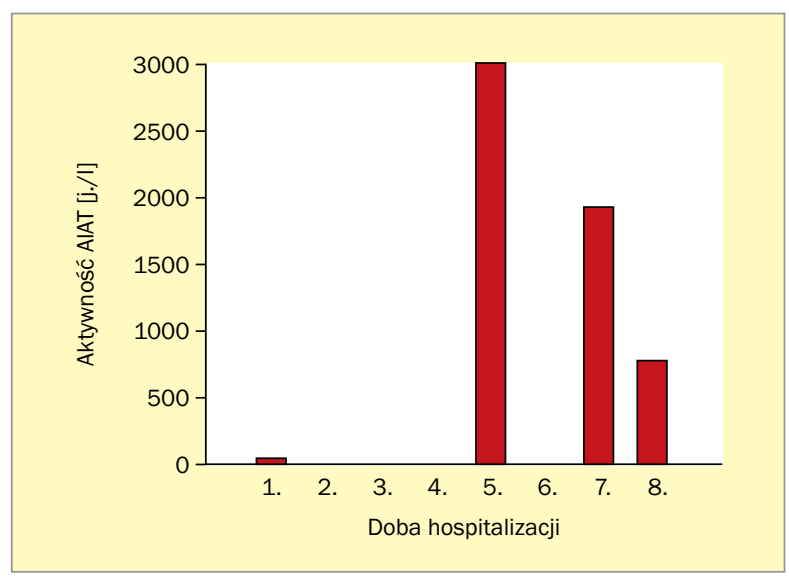

Rycina 4. Zmiany aktywności aminotransferazy alaninowej (AIAT, alanine aminotransferase) w kolejnych dobach hospitalizacji

Istnieje wiele czynników mogących wywołać uszkodzenie mięśni, spośród których na szczególną uwagę zasługują: urazy, rozległe zabiegi operacyjne, długotrwały ucisk mięśni, porażenie prądem, stany padaczkowe, udar cieplny, hipertermia złośliwa i złośliwy zespół neuroleptyczny, hipotermia, hipofosfatemia, hipokaliemia, hipomagnezemia, hipo- i hipernatremia, hipokalcemia, cukrzycowa kwasica ketonowa, nieketonowa hiperglikemia hiperosmolarna, zakażenia, złośliwy zespół neuroleptyczny, śpiączka hiperosmolarna, fibraty, kwas acetylosalicylowy [1, 5].

W kontekście szeroko stosowanego leczenia statynami należy zaznaczyć możliwość wystąpienia rabdomiolizy postatynowej, aczkolwiek częstość tego powikłania wynosi zaledwie 0,02\% [4]. W świetle najnowszych wytycznych nie należy włączać terapii statynami, gdy wartość CPK 4-krotnie przekracza ULN, a odstąpienie od terapii statynami jest wskazane przy stężeniu CPK przewyższającym ULN 10-krotnie [7]. Miopatię postatynową rozpoznaje się zgodnie z kryteriami Muscle Safety Expert Panel, które obejmuja bóle mięśniowe, skurcze, osłabienie siły mięśniowej zlokalizowane głównie w obrębie mięśni tułowia i proksymalnych części kończyn [8]. W takim przypadku dolegliwości ustępują w ciągu 2-3 tygodni od odstawienia statyny [4].

Ostatnio zauważalna jest moda na podejmowanie ekstremalnego wysiłku fizycznego przez osoby bez uprzedniego przygotowania, co może skutkować ciężkimi powikłaniami, takimi jak utrata przytomności z urazem, uszkodzenie mięśni, zespół ciasnoty przedziałów powięziowych z uszkodzeniem nerek. Tego typu aktywność powinna wiązać się z odpowiednim przygotowaniem kondycyjnym, najlepiej przy pomocy doświadczonego trenera. Należy również pamiętać o konieczności odpowiedniego nawodnienia organizmu przed i w trakcie wysiłku.

U przedstawionego pacjenta kombinacja wzrostu stężenia TnT, aktywności CPK oraz wyższego odejścia punktu J w EKG mogły sugerować ACS i stanowić wskazanie do wykonania koronarografii, co w przypadku obciążenia środkiem kontrastowym przy rabdomiolizie mogłoby prowadzić do nasilenia uszkodzenia nerek. Dodatkowo rozpoznanie w takim przypadku ACS wiąże się z włączeniem podwójnej terapii przeciwpłytkowej.

\section{Podsumowanie}

Przedstawiony wyżej przypadek wskazuje na konieczność uwzględniania pozawieńcowych przyczyn nagłego wzrostu markerów uszkodzenia mięśnia sercowego, szczególnie u młodych pacjentów bez dodatkowych czynników ryzyka sercowo-naczyniowego. Podaje on również w wątpliwość wartość zdrowotną ekstremalnych wysiłków u nieprzygotowanych zawodników - również z młodych grup wiekowych.

\section{Abstract}

We present a case of 34-year-old patient hospitalized with suspicion of acute coronary syndrome after loss of consciousness caused by extreme physical effort during mountain running. During the hospitalization we observed the increase of level markers of muscle damage and hepatic failure. The diagnosis rhabdomyolysis was settled.

The clinical symptoms were retreated and the laboratory parameters go improved.

Key words: extreme physical effort, rhabdomyolysis, hepatic failure, renal failure, acute coronary syndrome

Folia Cardiologica 2017; 12, 3: 298-302 


\section{Piśmiennictwo}

1. Zwolińska G. Choroby układu nerwowo-mięśniowego. Choroby mięśni szkieletowych. Rozpad mięśni szkieletowych. In: Gajewski P. ed. Interna Szczeklika 2016. Medycyna Praktyczna, Kraków 2016: 2203.

2. Małecki R. Rabdomioliza - postępowanie w warunkach opieki podstawowej. Kardiol na co Dzień. 2007; 2: 64-68.

3. Marino PL, Sutin KM. Intensywna Terapia. Elsevier Urban \& Partner, Wrocław 2009: 747.

4. Wełnicki M, Mamcarz A. Mała encyklopedia statyn. Medical Education, Warszawa 2013: 73-76.
5. Sarwiński P, Kącka A, Kosińska A, et al. Rabdomioliza w praktyce anestezjologa i intensywisty. Anest Ratow. 2012; 6: 442-450.

6. Bobilewicz DM. Rabdomioliza: gdzie i kiedy? In Vitro Explorer, Przegl Med Lab. 2011; 12: 3-5.

7. Catapano A, Graham I, Backer GDe, et al. Wytyczne ESC/EAS dotyczące leczenia zaburzeń lipidowych w 2016 roku. Kardiol Pol. 2016; 74(11): 1234-1318, doi: 10.5603/kp.2016.0157.

8. Mohaupt MG, Karas RH, Babiychuk EB, et al. Association between statin-associated myopathy and skeletal muscle damage. CMAJ. 2009; 181(1-2): E11-E18, doi: 10.1503/cmaj.081785, indexed in Pubmed: 19581603. 